\title{
Determinants of Fisher's Choice of Fishing Activity along the Volta Lake in Yeji, Ghana
}

\author{
Saagulo M. N. \\ Association of Church-based Development Projects, RESULT- \\ Project, Bolgatanga Regional Office, Ghana \\ saagulomauricenala@yahoo.com
}

Alhassan, E. H.

DDepartment of Fisheries and Aquatic Resources Management, University for Development Studies, Tamale, Ghana

and

Amikuzuno, $\mathbf{J}$.

Department of Climate Change and Food Security, University

for Development Studies, Tamale, Ghana

DOI//http://dx.doi.org/10.4314/gjds.v14i2.6

\begin{abstract}
The study examined factors that influence people's decision to engage in the fishery-related activities in Yeji, a major inland fishing town in Ghana. A total of 304 respondents were randomly selected and interviewed using semi-structured questionnaire. The analysis was done using the Ordered Probit Model and descriptive statistics. The study revealed that fishers in Yeji depend on the small-scale fisheries as their source of livelihood. The Ordered Probit regression analysis showed that the likelihood to engage in the fishery-related activities was significantly influenced by factors such as fishers' level of education, average daily catch, gear ownership (boat), credit access, fishing experience, income and household size. The study revealed that lack of credit access as affirmed by majority (82\%) of the respondents as the major challenge faced in the study areas. It is concluded that the fisheries sub-sector has the potential to boost economic growth, reduce poverty and ensure household food security in Yeji. It is therefore recommended that Ghana government through the Fisheries Commission should put in place sustainable measures and strategies that would ensure availability of fishing nets and boats for rural poor fishers.
\end{abstract}

Key words: Volta Lake, Determinants, Fishing Experience, Likelihood, Ordered Probit Model 


\section{Introduction}

Small freshwater pelagic fisheries in closed lakes are very important to millions of people in sub-Saharan Africa, supporting livelihoods and ensuring food security (Levison et al., 2012). Ghana's fisheries sector constitutes an important sector in national economic development. It is estimated that the fisheries sector contributes $3 \%$ of the total Gross Domestic Product (GDP) and 5\% of the agriculture GDP (FAO, 2014). Also, the fisheries sector contributes significantly to the national economy in terms of food security, employment, poverty reduction and foreign exchange earnings (BoG, 2008).

The fisheries sector plays important roles in providing food and income in many developing countries including Ghana, either as a stand-alone activity or in association with crop production and livestock rearing (Allison, 2001). However, the potentials of the fishery industry in reducing poverty and ensuring food security in Ghana, has been declining over the years. It is very obvious that there is paucity of information or no substantial in-depth study on the factors that determine people's choice of fishing activity in Yeji. The challenges identified to be associated with the fishery sector are mostly general, including those of marine and inland capture fisheries.

The full knowledge of the determinants of fisher's choice of activity, prospects and challenges of the sub-sector in Yeji will help in the development of strategies that build resilience in fishing communities along the Volta Lake in Yeji, especially the fishing households; hence the need for this study.

\section{Methodology}

\section{Study Area and Dataset}

The study was conducted in Yeji, the capital of Pru District in the Brong-Ahafo Region (Fig. 1), a major inland fishing town in Ghana. Yeji is located on the southern bank of the White Volta River in the Brong Ahafo Region (Pru District Assembly, 2015). The District has a total population of 129,248 out of which 65,832 are men and 63,416 are women (GSS, 2010). The major occupation of the inhabitants of Yeji is farming. The major crops cultivated are mainly yam, rice, maize, cassava, groundnuts, guinea corn, beans, and vegetables. Other economic activities in Yeji include: fishing, fish mongering, general trading, teaching among others (Pru District Assembly, 2015). 


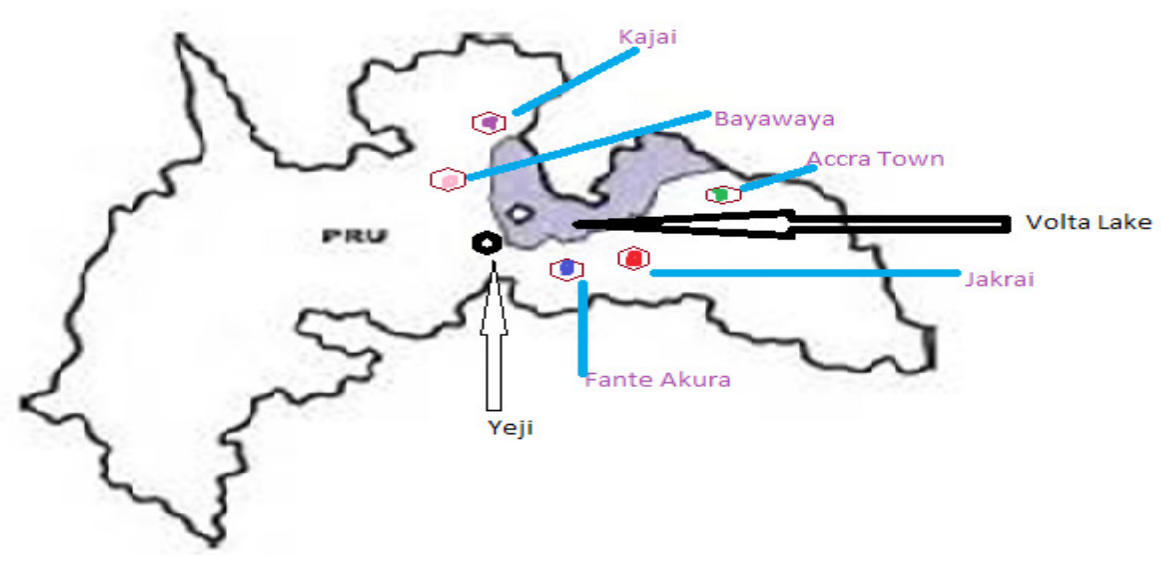

Figure 1: Pru District map showing the sampled communities

Source: ghanadistricts.com (Adopted and Modified, 2016)

Primary data was used for the study. The data was obtained from the targeted fishers (fish harvesters, fish mongers/ processors, marketers, fishing net weavers/ menders/ repairers, fish consumers) and people engaged in fishery-related activities using interviews, observations and focus group discussions.

The multistage sampling technique was employed. In the first stage, purposive sampling technique was employed to select six communities within the Pru District (Yeji, Fante Akura, Accra Town, Jaklai, Bayawaya and Kajai) as the communities sampled were among the most predominant fishing communities in the district. For an unknown population, Tabachnick and Fidell (2007) indicated that, for factor and regression analysis, $\mathrm{N}>=50$ $+8^{*} \mathrm{M}$ is adequate. Where $\mathrm{N}$ is sample size and $\mathrm{M}$ is number of independent variables in the regression. This study has 13 independent variables; hence a sample size of 50 $+8^{*} 13=154$ is adequate. However, a sample size of 306 was chosen such that findings from the research would be more representative. In the second stage, simple random sampling technique was used to select three hundred and six respondents with fifty one respondents from each of the 6 communities for interview. This was to examine the extent to which certain factors affect the respondents' decision to go into the fishery-related activities. The simple random sampling technique was used to enable every member of the population to have a fair chance of being selected. Two of the questionnaires were rejected as there were several missing data or incompleteness. Data based on 304 questionnaires were used in the analysis.

The study generated both qualitative and quantitative data through field household survey. The instrument used for data collection is a questionnaire. The questionnaire 
captured both closed and open-ended questions that sourced information on various household and demographic characteristics such as sex, age, fishers' educational level, fishers' experience level as well as socio-economic factors that influence peoples' decision to engage in the fishery-related activities. The various actors (fishers, fish mongers/ processors, marketers, fishing net weavers/ menders/ repairers, fish consumers) in the fisheries sub-sector were interviewed separately. The data was processed using Stata version 11 software and Microsoft Office Excel.

\section{The Ordered Probit Regression}

The theoretical model of the Ordered Probit (OP) regression model was formulated to identify the factors that influence people's decision to go into fishing. Several factors including socio-demographic factors, income, access to the resources, types of gear are expected to influence the kind and number of fishery-related activities a fisher engages.

The Ordered Probit model is built around a latent regression in the same manner as the Binomial Probit model (Maddala, 1983; Greene, 2003) as follows:

$\dot{y}=x^{\prime} b+\varepsilon$

$\dot{y}$ is not observable, instead we observe

$\mathrm{y}=0$ if $\dot{\mathrm{y}} \leq \mu_{1}$

$\mathrm{y}=1$ if $0<\dot{\mathrm{y}} \leq \mu_{1}$

$\mathrm{y}=2$ if $\mu_{1}<\dot{\mathrm{y}} \leq \mu_{2}$

$\mathrm{y}=\mathrm{j}$ if $\mu_{\mathrm{j}-1}<\dot{\mathrm{y}}$

Where $\mathrm{x}$ is a vector of independent variables; The $\mu$ 's are unknown parameters to be estimated with $b$ and $\varepsilon$ is the two sided error term with mean zero and constant variance.

The probabilities are given as follows:

$\operatorname{prob}(y=o / x)=\varnothing\left(-x^{\prime} \beta\right)$

$\operatorname{prob}(y=1 / x)=\varnothing\left(\mu_{1}-x^{\prime} \beta\right)-\emptyset\left(-x^{\prime} \beta\right)$

$\operatorname{prob}(y=2 / x)=\emptyset\left(\mu_{2}-x^{\prime} \beta\right)-\emptyset\left(\mu_{1}-x^{\prime} \beta\right)$

$\operatorname{prob}(y=j \mid x)=1-\emptyset\left(\mu_{j-1}-x^{\prime} \beta\right)$

where:

$\beta s=$ corresponding coefficients of the variables

$\theta s=$ the cut points (thresholds) for calculating the probabilities 
For all the probabilities to be positive, we must have

$$
\begin{aligned}
& 0<\mu_{1}<\mu_{2} \ldots \mu_{j-1} \\
& \frac{\partial \operatorname{prob}(y=0 \mid x)}{\partial x}=-\varnothing\left(-x^{\prime} \beta\right) \beta_{j}
\end{aligned}
$$

$\frac{\partial \operatorname{prob}(y=0 \mid x)}{\partial x}=-\varnothing\left(-x^{\prime} \beta\right)-\emptyset\left(-x^{\prime} \beta\right) \beta_{j}$

$\frac{\partial \operatorname{prob}(y=0 \mid x)}{\partial x}=-\varnothing\left(\mu-x^{\prime} \beta\right) \beta_{j}$

The log-likelihood function and its derivatives are obtained by Maddala (1983). The marginal effects of changes in the regressors for the first three probabilities in equation 3 are given as;

The empirical component of the Ordered Probit Model is built around the dependent variable, (a set of fishery-related activities) which respondents can engage in ranging from one to four. The four main fishery-related activities were identified as: fish harvesting; fish trading; fish processing and net making/ mending. If a respondent engages in one, two or three of the fishery-related activities, he/ she is a partial adopter, however, the one who engages in three activities is assumed to be better off than the one who engages in two activities. In the same way, the one who engages in two activities is better off than the one who engages in one activity. If a respondent engages in all the four activities, then he is a full adopter and scores four and is assumed to be better off than all the levels of engagement.

The empirical model may be stated as follows:

$Y_{i}=\beta_{0}+\beta_{1}$ Income $+\beta_{2}$ Fishing_Experience $+\beta_{3}$ Sex $+\beta_{4}$ Dependents $+\beta_{5}$ Housenold_Size $+\beta_{6}$ Education $+\beta_{7}$ Boat_Ownership $+\beta_{8}$ Net_Ownership $+\beta_{9}$ Average_Daily_Catch $+\beta_{10}$ Access_to_Fishery-Resource $+\beta_{11}$ Community_Status $+\beta_{12}$ Access_to_Credit + $\beta_{13}$ Quantity_Consummed $+\mu_{1}$

8

Where;

$\mathrm{Y}=\mathrm{o}$ if a respondent is not engaged in any of the four categories of the fishery-related activities under review;

$\mathrm{Y}=1$ if a respondent engages in any one of the four categories of the fishery-related activities;

$\mathrm{Y}=2$ if a respondent engages in any two of the four categories of the fishery-related activities; 
$\mathrm{Y}=3$ if a respondent engages in any three of the four categories of the fishery-related activities; and

$\mathrm{Y}=4$ if a respondents engages in all the four categories of the fishery-related activities.

Where $\beta_{1,} \beta_{2,} \beta_{3}, \beta_{4,} \beta_{5}, \beta_{6}, \beta_{7}, \beta_{8,} \beta_{9}, \beta_{10}, \beta_{11}, \beta_{12}$ and $\beta_{13}$ are the associated coefficients to be estimated. Table 1 presents the description, measurement and a priori expectation of explanatory variables $\beta_{\mathrm{o}}=$ intercept $\mu_{1}=$ Error term

The ordered probit was chosen over the other binary regression models because it gives effects of changes in the explanatory variables on all the observed levels of the dependent variable.

Table 1: Description, measurement and a priori expectation of explanatory variables

\begin{tabular}{|c|c|c|c|}
\hline Variable & Description & Measurement & a priori expectation \\
\hline Income & Income of respondents & Ghana cedi per week & $+/-$ \\
\hline Experience & Number of years of fishing & Years & $-1+$ \\
\hline Sex & Sex of respondent & $\begin{array}{l}\text { Dummy: } \\
1 \text { = male, } \mathrm{o}=\text { female }\end{array}$ & $+/-$ \\
\hline $\begin{array}{l}\text { Number of } \\
\text { Dependents }\end{array}$ & $\begin{array}{l}\text { Number of people who depend } \\
\text { on the respondent for support }\end{array}$ & Number of people & $+/-$ \\
\hline Household Size & $\begin{array}{l}\text { Number of people who eat from } \\
\text { the same pot }\end{array}$ & Number of people & + \\
\hline $\begin{array}{l}\text { Level of } \\
\text { Education }\end{array}$ & Number of years in school & Years & + \\
\hline Boat Ownership & $\begin{array}{l}\text { Whether the respondent owns } \\
\text { a boat or not }\end{array}$ & Dummy: $1=$ yes, $0=$ no & $+/-$ \\
\hline Net Ownership & $\begin{array}{l}\text { Whether the respondent owns } \\
\text { a net or not }\end{array}$ & Dummy: $1=$ yes, $\mathrm{o}=$ no & $+/-$ \\
\hline $\begin{array}{l}\text { Average Daily } \\
\text { Catch }\end{array}$ & Quantity of fish caught in a day & $\mathrm{Kg}$ & $+/-$ \\
\hline $\begin{array}{l}\text { Access to the } \\
\text { fishery }\end{array}$ & Access to the fishery resource & Dummy: 1 = yes, $\mathrm{o}=$ no & $+/-$ \\
\hline $\begin{array}{l}\text { Community } \\
\text { Status }\end{array}$ & $\begin{array}{l}\text { Whether the respondent is a } \\
\text { native or non-native }\end{array}$ & $\begin{array}{l}\text { Dummy: } \\
1 \text { = Native, } \mathrm{O}=\text { non-native }\end{array}$ & $+/-$ \\
\hline Access to Credit & $\begin{array}{l}\text { Whether the respondent has } \\
\text { access to credit or not }\end{array}$ & Dummy: $1=$ yes, $0=$ no & $+/-$ \\
\hline $\begin{array}{l}\text { Quantity } \\
\text { Consumed }\end{array}$ & $\begin{array}{l}\text { Quantity of the fish consumed } \\
\text { in the household }\end{array}$ & $\mathrm{Kg}$ & $+/-$ \\
\hline
\end{tabular}




\section{Results and Discussion}

The study recorded household sizes that ranged from 1 to 36 persons with an average size of 9 persons. The large household size was attributable to the polygamous marriages and the extended family system that is commonly practiced in the study area. This is evident that their livelihoods will likely differ with regards to their status. It will equally have food security, income and other related implications on one hand, as Mhinte (2000), observed that having a large household size who are not productive usually could result in food insecurity as the labor force decreases. On the other hand, the larger household size could be a source of available labour for fishing and other activities such as farming and petty trading.

The study revealed that half $(50 \%)$ of the respondents had no formal education. Those aged 60 and above were mostly without formal education, but majority of the fishers with primary education fell within the 20-49. This could probably be due to the fact that many of the older fishers at their youthful age had to help their parents in their fields of endeavour and hence did not attach much essence to education at that early stage of their lives. Interestingly, most of them probably realised the essence of education later in life and had to ensure that their wards had some form of education.

On one hand, the implication of the low educational status of the respondents could be that, the adoption of modern technologies could be hampered, since level of education is known to be influential in adoption decisions (CMMYT, 1993). On the hand, it could serve as an indicator that, the small-scale fishery sub-sector supports the majority of the active unemployed youth who have no special skills, thus curbing the youth unemployment menace in the country. Education could have an effect on the incomes of people engaged in the fishery sub-sector as Phillipo (2008) observed that higher returns among farmers undertaking off-farm activities were from those with more years of formal education.

\section{Factors Influencing People's Decision to Engage in the Fishery-related Activities in Yeji}

Results of the maximum likelihood estimation results of the Ordered Probit model are presented in Table 2. From Table 2, the LR $\mathrm{Chi}^{2}$ of 36.78 the Prob $>\mathrm{Chi}^{2}$ of 0.0004 , imply that all the variables jointly determine the factors influencing people's decision to engage in the fishery-related activities in Yeji.

The fisher's level of education, average daily catch, fishing gear ownership (boat), and access to credit positively influenced fishers' decision to engage in the fishery activities (Table 2). This implies that the probability of engaging in the fishery activities was greater for fishers who had a higher average daily catch, fishers who own their boats, 
fishers who had access to credit and fishers who had some form of education. However, experience, income and household size negatively influenced people's decision to engage in the fishery-related activities (Table 2). This actually means that, fishers with higher experience, higher income and larger household sizes turn to concentrate on fewer fishery-related activities. That is people turn to specialize in few of the fishery-related activities with increasing experience.

Table 2: Maximum likelihood estimates of the Ordered Probit Model

\begin{tabular}{|l|l|l|}
\hline Variable & Coefficient & Standard error \\
\hline Income & $-0.0920196^{* *}$ & 0.0365289 \\
\hline Experience & $-0.0196489^{*}$ & 0.009415 \\
\hline Sex & -1.00354 & 0.5430151 \\
\hline No of dependents & $0.0568847^{*}$ & 0.0213941 \\
\hline Household size & $-0.0955649^{* *}$ & 0.0474235 \\
\hline Level of education & $0.2818817^{*}$ & 0.2255145 \\
\hline Boat ownership & $0.8309332^{* *}$ & 0.5028582 \\
\hline Fish net ownership & 0.8029768 & 0.5141301 \\
\hline Average daily catch & $0.004512^{* *}$ & 0.002296 \\
\hline Access to the fishery resource & -0.3124199 & 0.2352983 \\
\hline Community status & -0.5805503 & 0.5791526 \\
\hline Daily fish consumption & -0.0045593 & 0.0079904 \\
\hline Credit access & $0.6502304^{* *}$ & 0.2799268 \\
\hline & -0.3455891 & 0.579599 \\
\hline /cut1 & 0.8416189 & 0.5904741 \\
\hline /cut2 & 2.342272 & 0.6712 \\
\hline /cut3 & & \\
\hline
\end{tabular}

LRChi ${ }^{2}(12)=36.78$, Prob $>C h i^{2}=0.0004$, Pseudo -squared $=0.1429$, Log likelihood $=-110.31525$

*** Significant at $1 \%,{ }^{* *}$ significant at $5 \%,{ }^{*}$ significant at $10 \%$

Dependent variable (Y): Fishery-activities (Fish harvesting, Fish processing, Fish trading and Net mending)

The marginal effects of the Ordered Probit estimates of the factors influencing fishers' decision to engage in the fishery-related activities are presented in Table 3. In the model, out of the thirteen explanatory variables, eight were found to be statistically significant. The study revealed that income, experience, sex, household size, gear ownership (boat and net), average daily catch and access to credit were found to have significant influence on peoples' decision to engage in the fishery activities (Table 3 ).

From the marginal effects of the Ordered Probit estimation, income was found to have a positive significant ( $5 \%$ ) effect on peoples' decision to engage in the fishery-related 
activities. That is, if the income of a fisher increases by GHS 1.00, then the probability that he/ she will engage in more of the fishery-related activities will also increase by 0.036, holding other factors constant. This implies that the higher the income of a fisher, the greater his/ her probability of engaging in more of the fishery-related activities.

Fishing experience was found to have a positive significant (10\%) effect on people's decision to engage in the fishery-related activities. This met the a priori expectation. It is generally believed that fishing experience broadens the horizon of an individual and therefore would enable him/her to engage in many of the fishery-related activities. The results revealed that fishers with higher experience were engaged in more of the fishery-related activities than fishers with less experience (Table 3). That is, if experience increases by 1 year, the probability that a fisher will engage in more of the fishery-related activities also increases by 0.0361 , holding other factors constant.

The coefficient of the sex variable (dummy coded $\mathrm{o}=$ female, $1=$ male) was positive, which implies that men had a higher probability of engaging in more fishery-related activities compared to the women. This meant that for every additional man that is engaged in the small-scale fishery sub-sector, the probability of engaging in more fishery-related activities is increased by $37 \%$.

Majority of the people engaged in fisheries because of the nature of the job. Gender plays a role in influencing the type of activities men and women engaged in. Women basically avoid masculine jobs even in their quest for power and access to resources. This could also be largely attributed to their upbringing. This finding lends support from Sonjiwe et al. (2015) who reported that women are comfortable undertaking fish processing and trading than men. This however, is contrary to the a priori expectations that the other fishery-related activities apart from fish harvesting favours the women more. Nonetheless, a possible reason could be from the fact that higher numbers of men were engaged in fish trading aside fish harvesting and net mending. Thus, most of the men also do fish trading aside harvesting and net mending compared to the women who were largely involved in fish processing and trading. About $56 \%$ of the respondents (men and women) were engaged in fish trading with $37 \%$ being women and 19\% men. The percentage of men engagement in fish trading is just about half that of women (19\%) who engaged in fish trading, hence the positive coefficient is justified.

The average household size was 9 persons. Large household size could imply large working labour force in a family, meaning the household may not need to hire additional labour. The money for hiring labour could be saved and channeled to purchasing other fishing inputs. This will encourage households to actively participate in many of these fishery-related activities due to the availability of labour. Household size was expected to have a positive relationship with the kind and number of fishery-related activities 
people undertake. The study revealed that household size was significant at 5\% (Table 3), implying that an increase household size of a fisher increases by one person will likely lead to 0.038 increase in the probability of that fisher engaging in more of the fisheryrelated activities. This finding meets the a priori expectation. It is also in congruence with the findings of Bekele et al. (2000) and Million and Belay (2004).

Gear ownership (boat and net) (dummy coded o = owns gear, $1=$ does not own gear) was found to have a negative (-0.2925475 and - 0.2827528) influence on the decision to engage in the fishery-related activities (Table 3). For fishermen who do not own either a boat or fishing net, the probability of engaging in such fishery-related activities is reduced by 0.293 and 0.283 , respectively. This is plausible because if one does not own a boat or net and wants to engage in fishing, the fellow has to rent and pay between GHS 50.00 to GHS 100.00 averaging GHS 75.00 per week. This is enough to discourage people who do not have such equipment from engaging in activities in the sub-sector.

Average daily catch which was expected to have a significant positive influence on the kind and number of fishery related activities was found to be negative. The negative signed coefficient (-0.002) (Table 3) implies that, as the daily average catch of individuals engaged in fish harvesting decreases, the probability of the them engaging in other activities such as fish trading, processing and net mending increases. That is, the probability of engaging in the other fishery-related activities when harvesting decreases is 0.002 ceteris paribus. It is however, not a linear relationship because the fisher has to buy from other sources before it can be processed and sold or has to buy fresh fish from one source and sell it in that state to market women who then process it for sale. Also, the fellow's probability of engaging in the other fishery-related activities as processing, trading and net mending) will vary.

Access to credit is an important contributing factor to almost all business ventures including fishing, and as it is to the fishery related activities. Fishers who did not have access to financial assistance tend to participate less in the fishery related activities. The probability of participating in a fishery-related activity for fishers without credit access is reduced by about $25 \%$ (Table 3). Fishers with credit access have an advantage in acquiring more and efficient fishing gears compared to their counterparts who do not have access to credit. Credit access will encourage the fishers to exploit all the fisheryrelated activities and make more gains. Credit access in the long run would improve the food security status and poverty situation of a household because more investment means higher returns and the ability to meet household food demand, ceteris paribus. 
Table 3: Marginal effects of the Ordered Probit estimation

\begin{tabular}{|l|l|l|}
\hline Variable & $\mathrm{dy} / \mathrm{dx}$ & Standard error \\
\hline Income & $0.0361979^{* *}$ & 0.01725 \\
\hline Experience & $0.0077293^{*}$ & 0.00463 \\
\hline Sex & $0.3706961^{*}$ & 0.19866 \\
\hline Number of dependents & -0.0223769 & 0.01993 \\
\hline Household size & $0.0375926^{* *}$ & 0.01855 \\
\hline Level of education & -0.1103824 & 0.08748 \\
\hline Boat ownership & $-0.2925475^{* *}$ & 0.14643 \\
\hline Net ownership & $-0.2827528^{*}$ & 0.15026 \\
\hline Average daily catch & $-0.0017749^{* *}$ & 0.0009 \\
\hline Access to the fishery resource & 0.1231797 & 0.09252 \\
\hline Community status & 0.2083126 & 0.17999 \\
\hline Access to credit & $-0.2548818^{* *}$ & 0.10564 \\
\hline Quantity consumed in the household & 0.0017935 & 0.00314 \\
\hline
\end{tabular}

*** significant at $1 \% * *$ significant at $5 \% *$ significant at $10 \%$

Dependent variable (Y): Fishery-related activities (Fish harvesting, Fish processing, Fish trading and Net mending)

\section{Challenges Facing Fishers in the Small- scale Fishery Sub-Sector in Yeji}

Bank of Ghana (2008), revealed that the problems of the fishing industry in Ghana are undeniably mottled; they range from inadequate infrastructure such as landing sites leading to high post-harvest losses, poor fishing vessels and gear, inadequate storage facilities in the fishing centres, lack of enforcement of the regulatory framework regarding fishing in Ghana's waters, and inadequate monitoring of fishing in Ghana's waters (BoG, 2008).

The challenges based on individual respondent's responses were interlinked. Majority (82\%) of the respondents (Figure 2 ) affirmed that lack of access to financial assistance as the major challenge faced in the study area. From the results, $28 \%$ of the respondents reported that low fish prices especially in the main season were one of the major challenges facing fishers in the study area (Figure 2). The reason as explained by some of the fishers was that, some of them were being pre-financed by the market queens who coerced fishers to sell their fish at lower prices to them. The market queens in turn bought at lower prices as a way of receiving indirect interest from the fishers. This agrees with the findings of Levison et al. (2012) who reported that fish harvesters complained of very low prices offered by processors whilst fish harvesters on the other hand complained about very high prices of fish charged by fish harvesters. Just as reported 
by Levison et al. (2012), this could mainly be due to information asymmetry between buyers and fishers, which is common in African small-scale fisheries of which Ghana is no exception. During the major fishing season where fishers caught in excess, there was always a glut in the market, hence fishers, particularly those engaged in only harvesting were forced to sell their fish at lower prices to market queens. The situation is somehow better for fishers engaged in both harvesting and processing since they can process and store for sale in the lean season.

In line with poor prices, poor market access and market information as reported by $8.33 \%$ of the respondents, are key challenges faced by fishers in the study area (Figure 2). The reasons being that fish marketing business is vulnerable and price sensitive, hence the traders give the wrong information in order to buy the fishes at lower prices.

Important among the challenges is the inaccessibility of fishing nets and boats as indicated by $10.67 \%$ of the respondents (Figure 2). Fishers in the interior villages had to travel long distances in order to purchase nets. The transportation cost adds up to the price of the nets, and sometimes the fatigue fishers had to go through before purchasing nets is a disincentive to young people from entering the business.

It was reported that the trees used as foundation for building boats were scarce in the fishing communities. Boat builders who access the few trees around to build boats charge exorbitant prices, which fishers sometimes are unable to buy. Poor catch resulting from depletion of the fishery resources was also reported by $13.33 \%$ of the respondents as one of the challenges faced by fishers in the study areas. Few fishers (3\%) also reported illegal means of fishing such as light fishing, pair trawling and bamboo fishing as a challenge facing them (Figure 2). 


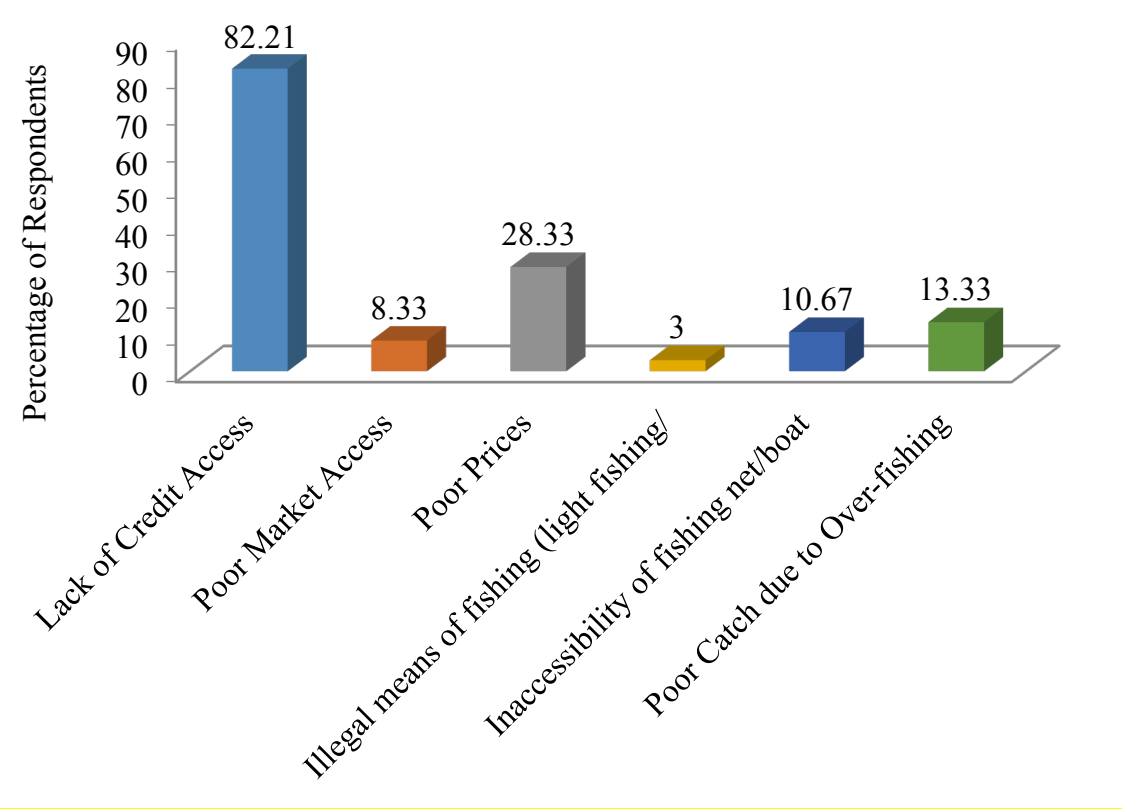

Figure 2: Challenges facing fishers in the fishery sub-sector in Yeji

\section{Prospects of the Fishery Sub-Sector in Yeji}

Results from the study (Table 4) showed that 75 (25\%) of the respondents from the various communities interviewed, indicated that the fishery sub-sector has the potential of improving livelihoods of many households in the Pru District. About 72 (24\%) of the respondents also mentioned that despite the challenges, the fishery sub-sector has the potential of employing the abled bodied youth who have no form of employment. The fishers in their own initiatives along with government could lead to the development of markets, processing and storage facilities in the fishing communities, which would in a long way strengthen the infrastructural development of the area. This in the long run will boost the fishery sub-sector by aiding the fish harvesters and the market women process and store fish for a longer period of time, thus solving the problem of periodic fish shortages on the market.

Richster (2010) reported that most MMDAs have refused to gazette community bye laws, rendering the Community-based Fisheries Management Committees ineffective. Richster (2010) also reported that politicians also clandestinely usurp and undermine the authorities of chief fishermen. However, the study revealed that community bye laws have been put in place and enforced to ensure that there is a minimum fallow period of 3 months in a y ear. This is the period where many fish species reproduce, thereby avoiding extinction of uncommon fish species in the Volta Lake. 
Table 4: Prospects of the fishery sub-sector in Yeji

\begin{tabular}{|l|l|}
\hline Prospect & Percentage \\
\hline Improving Livelihoods & 25 \\
\hline Employing Abled unemployed youth & 24 \\
\hline $\begin{array}{l}\text { Physical infrastructural development (storage/ processing facilities and } \\
\text { market development) }\end{array}$ & 20 \\
\hline Community Bye-Laws to restrict fish harvesting & 31 \\
\hline Total & $\mathbf{1 0 0}$ \\
\hline
\end{tabular}

\section{Conclusion}

This study assessed the determinants of fishers' choice of fishing activity along the Volta Lake in Yeji. The fishing and fishery-related activities serve as source of income and food for small-scale fishers. Small-scale fisheries provide significant contribution to the incomes of the people engaged in the fisheries sub-sector in Yeji. This in the long run could lead to enhanced food security as fishers could use incomes earned to buy food. The small-scale fishery sub-sector also offers diversified livelihood options such as fish harvesting, net making and mending and general fish trading which the youth of Yeji can take up as a vocation.

Based on the findings of the study, the following recommendations are made for consideration in policy formulation: any intervention to improve the participation of people in the fishery-related activities in Yeji, should consider the specific factors such as fishers' level of education, average daily catch, gear ownership (boat), credit access, fishing experience, income and household size that influence fishers' decision to engage in the fishery-related activities. Amongst the challenges hindering fishers' ability to maximise production in the sub-sector in Yeji is limited access to fishing gear (nets and boats). Based on that, the government of Ghana through the Fisheries Commission should put in place sustainable measures/ strategies that would ensure availability of fishing nets/ boats to fishers. 


\section{References}

Allison, E. (2011). Aquaculture, fisheries, poverty and food security: Policy, Economics and Social Sciences; The World Fish Centre Penang, Malaysia.

Bank of Ghana (2008). The fishing sub-sector and Ghana's economy. The Head Research Department Bank of Ghana Accra, Ghana.

Bekele, H., Verkuijl, H., Mwangi, W. and Tanner, D. (2000). Adoption of improved wheat technologies in Adaba and Dodola Woredas of the Bale highlands, Ethiopia. Mexico, D.F.: Organisation.

CMMYT (1993). The adoption of agricultural technology: a guide for survey design CMMYT economics programme. Mexico, pp.88.

Food and Agriculture Organization FAO (2001). FAO yearbook fishery statistics. Aquaculture production 1999. Vol. 88/2, Food and Agriculture Organization of the United Nations, Rome, Italy, pp. 178.

FAO (2014). The state of world fisheries and aquaculture; opportunities and challenges.

Ghana Statistical Service (2010). 2010 population and housing census.

Greene, W. H. (2003). Econometric Analysis. New Jersey-U.S.A: Prentice Hall Griffin, 736740 pp. Retrieved from images/stories/pdf/officialreports/20121030_fish_en.pdf. Accessed on $25^{\text {th }} 2016$.

Levison, C., Daniel, J., Regson, C. and Joseph, N. (2012). The structure and margins of the Lake Chilwa Fisheries in Malawi: A value chain analysis; World Fish Centre.

Maddala, G. S. (1983). Limited-dependent and qualitative variables in econometrics. New York: Cambridge University, pp. 6-26.

Mhinte, R. B. (2000). Analysis of rural households coping strategies against seasonal food insecurity. Dissertation for Award of Msc Degree at Sokoine University of Agriculture, Morogoro, Tanzania, pp. 121.

Million, T. and Belay, K. (2004). Determinants of fertilizer use in Gununo area. Accessed on $26^{\text {th }}$ July, 2016.

Phillipo, F. (2008). Contribution of income generating activities to household income in Kigoma Urban District. Dissertation for Award of Msc. Degree at Sokoine University of Agriculture, Morogoro, Tanzania, pp. 93.

Pru District Assembly (2015). The composite budget of the Pru district assembly for the 2015 fiscal year. Available at: www.mofep.gov.gh or www.ghanadistricts.com. Accessed on $29^{\text {th }}$ July, 2016. 
Richster N. A. A. (2010). Addressing the challenges in the fishing industry in Ghana. $\quad$ http://www.ghanaweb.com/GhanaHomePage/NewsArchive/artikel. php?ID =181878. Friday, 14 May 2010: Accessed on $7^{\text {th }}$ July, 2017.

Sonjiwe, A., Musuka, C. G. and Haambiya, L. (2015). The Contribution of artisanal fisheries towards livelihoods and food security among communities of Chanyanya Fishing Camp in Kafue District of Lusaka Province. International Journal of Forestry and Horticulture, 1(2), pp. 22-32.

Tabachnick, G. and Fidell, L. S. (2007). Experimental designs using ANOVA. Belmont, CA: Duxbury. 